\title{
PARTISIPASI PEREMPUAN DALAM LEMBAGA LEGISLATIF DI KABUPATEN KENDAL
}

\section{Oktaviani Adhi Suciptaningsih ${ }^{凶}$}

Universitas Sunan Muria Kudus, Jawa Tengah Indonesia

\section{Info Artikel}

Sejarah Artikel:

Diterima Juni 2010

Disetujui Juli 2010

Dipublikasikan September 2010

Keywords:

Legislature;

Participation of woman;

Gender.

\begin{abstract}
Abstrak
Partisipasi perempuan dalam politik merupakan bentuk emansipasi yang penting bagi perempuan untuk mencapai kesetaraan gender.Dalam penelitian ini, saya mengeksplorasi bagaimana partisipasi perempuan dalam Lembaga Legislatif di Kabupaten Kendal dan bagaimana peran perempuan dalam penentuan kebijakan di Lembaga Legislatif di Kabupaten Kendal. Metode penelitian menggunakan pendekatan kualitatif, pengumpulan data dilakukan dengan observasi, wawancara dan dokumentasi. Hasil penelitian menunjukkan bahwa partisipasi perempuan dalam Lembaga Legislatif di Kabupaten Kendal masih sangat rendah, dari 45 orang anggota dewan legislatif, hanya 4 orang saja yang perempuan. Padahal jumlah penduduk perempuan lebih banyak daripada penduduk laki-laki. Rendahnya partisipasi perempuan ini disebabkan karena banyaknya kendala yang menghambat perempuan untuk maju berpartisipasi dalam lembaga legislatif, diantaranya kendala psikologis, ekonomi, politik, dan sosial budaya. Yang sedikit inipun tidak memiliki kompetensi yang baik untuk memperjuangkan keadilan jender dalam kebijakan. Akibatnya, banyak kebijakan publik yang belum berperspektif gender.
\end{abstract}

\begin{abstract}
Women's participation in politics is a important emancipation strategy of women in achieving gender equality. In this article, I seek to discuss the participation of women in the parliamentary body in the district of Kendal and women's role in determining policy in the district. Method used in this research is observation and interview. Research result shows that women's participation in Kendal is still low; of the 45 legislative council members, only 4 are women, though the population of women outnumbers male population. The low participation of women roots from many barriers, such as psychological, economic, political, social and cultural barriers. This limited number also does not have enough competence to pass gender equality policies in the parliament. The consequence of low participation of women is the lack of gender perspective in the policy made by the legislative body.
\end{abstract}

(C) 2010 Universitas Negeri Semarang 


\section{PENDAHULUAN}

Anggapan secara umum, dunia politik merupakan dunia yang penuh dengan intrik. Panggung yang sarat dengan adu kekuatan, sarana orang-orang untuk unjuk kekuasaan, tempat orang yang bergelut untuk meraih, mempertahankan dan memperluas pengaruh. Politik adalah perebutan makna" kebenaran umum". Hal yang dianggap sebagai kebenaran umum itu akhirnya diputuskan sebagai sebuah kebijakan atau keputusan politik. Apa yang dianggap para pengambil keputusan sebagai kebenaran akhirnya harus diakui sebagai kebenaran bersama. Padahal keputusan politik ditentukan oleh segelintir orang yang umumnya adalah laki-laki, berasal dari kelas tertentu dan berpendidikan (Wijaksana, 2004:xi).

Berbicara soal kebenaran umum, tentu banyak yang menyangsikan. Apakah kebenaran itu sudah merupakan kesepakatan terutama kelompok masyarakat yang selama ini terpinggirkan dalam politik? Bagaimana kelompok terpinggirkan seperti masyarakat miskin, mereka yang hidup di daerah terpencil, kelompok penyandang cacat, usia lanjut dan perempua (sebagai bagian warga negara yang terbesar), dapat mengakui kebenaran itu jika pada prosesnya mereka yang lebih sering terabaikan?

Politik bukan saja bicara soal adu kekuatan atau adu pengaruh yang cenderung menguntungkan segelintir orang. Politik juga harus bicara soal partisipasi dan keterwakilan. Partisipasi dan keterwakilan yang dimaksud adalah bagaimana politik memiliki kemauan untuk mendorong dan mengakomodasi keberagaman masyarakat yang selama ini terpinggirkan, tak terkecuali perempuan. Sistem politik harus menghapus berbagai jenis diskriminasi dan subordinasi yang secara sengaja atau tidak sengaja dilakukan terhadap kelompok masyarakat terbesar tersebut. Untuk itu perempuan juga harus terlibat langsung dalam politik karena perempuan memiliki persoalan-persoalan khusus, sementara itu keterwakilan mereka dalam lembaga-lembaga strategis pembuat keputusan sangatlah rendah. Ketimpangan ini mengakibatkan perempuan sebatas sebagai penerima kebijakan tanpa memiliki akses dan kontrol untuk memberikan masukan, kritik atau perubahan kebijakan. Ketertinggalan perempuan di bidang ekonomi, pendidikan, ketenagakeijaan, kesejahteraan sosial dan lainnya harus dibaca sebagai akibat ketimpangan keterwakilan perempuan dalam perumusan kebijakan publik.

Tantangan politisi perempuan lebih berat dibandingkan perjuangan politisi laki- laki, tetapi semua itu harus dilakukan oleh kaum perempuan dan oleh karenanya mengapa mematok kuaota $30 \%$ perempuan di parlemen dalam Pemilu 2004 menjadi sangat penting dalam rangka tindakan affirmative action (tindakan khusus sementara) sekaligus memberikan kesempatan seluasluasnya bagi perempuan untuk berkiprah dalam dunia politik.

Basis pemikiran lainnya adalah keyakinan bahwa sangatlah penting bagi perempuan untuk meningkatkan partisipasi politiknya baik secara kuantitatif dan kualitatif, sebab dengan maju ke ruang publik dan menduduki tempat-tempat strategis pengambilan keputusan sebagai satu-satunya cara agar kepentingan mereka terwakili. Kepentingan tersebut harus diperjuangkan oleh kaum perempuan sendiri sebab tidak mungkin dapat dirumuskan secara baik oleh kaum laki-laki (Venny dalam Wijaksana, 2004: $x$ ).

Sudah waktunya memang, perspekif gender masuk ke segala lini kehidupan terutama dalam pengambilan keputusan dan kebijakan pemerintah dari tingkat pusat sampai daerah. Hal ini sesuai dengan Instruksi Presiden No. 9 Tahun 2000 tentang Pengarusutamaan Gender dalam setiap kebijakan dari tingkat pusat sampai daerah. Sistem politik lebih menguntungkan sifatsifat maskulin yang dimiliki oleh laki-laki.

Model politik lebih banyak ditentukan dengan sifa-sifat konfrontatif" menang" atau "kalah". Politik jauh dari menghormati nilai- nilai kolaboratif atau pembangunan konsensus. Berapapun sumbangan yang diberikan perempuan untuk partai sangat besar, menjadi tidak berarti karena kebijakan partai yang tidak menguntungkannya. 
Budaya patriarki dalam masyarakat telah menempatkan perempuan pada posisi yang selalu berada di bawah laki-laki (subordinat), rawan akan kecenderungan merebaknya berbagai stereotip (pelabelan negatif), marginalisasi (peminggiran dan pemiskinan perempuan), subordinasi (yang berdampak pada eksploitasi) dan tindakan-tindakan kekerasan (violence). Keputusan- keputusan penting yang menyangkut orang banyak dianggap terlalu riskan untuk diserahkan kepada perempuan (Sadli, 2010).

Perempuan sendiri acap kali menganggap politik itu sebagai permainan kotor. Anggapan ini telah memukul rasa percaya diri perempuan untuk berhadapan dengan proses politik. Ketidakpercayaan diri kerap menjadi penyebab utama tidak tampilnya perempuan dalam pentas politik formal seperti dalam partai politik, parlemen atau pemerintahan. Ketidakberuntungan perempuan secara sosial ekonomi telah menempatkan perempuan menjadi kelompok warga negara yang rentan akan kemiskinan, kebodohan, dan ketertinggalan. Akibatnya kesempatan perempuan untuk memperjuangkan haknya menjadi sangat kecil (Venny dalam Wijaksana, 2004:4).

Oleh karenanya sebagai langkah awal patutlah dicatat bahwa keterwakilan perempuan dalam politik telah menjadi sebuah wacana baru yang memasyarakat. Lambat laun orang akan sadar bahwa bicara soal demokrasi harus dimulai dari dua pihak, laki-laki dan perempuan. Tidak ada demokrasi jika hanya mementingkan satu pihak sembari mengesampingkan pihak lain. Resonansi ini hampir terdengar di semua lapisan masyarakat. Mengeras'atau melemahnya gaung itu akan ditentukan oleh wakil-wakil perempuan di gedung DPR dan DPRD di semua pelosok daerah nanti. Permasalahan penelitian ini difokuskan pada partisipasi perempuan dalam lembaga legislatif dan peran perempuan dalam penentuan kebijakan dalam lembaga legislatif di kabupaten Kendal.

\section{METODE PENELITIAN}

Berdasarkan permasalahan yang diajukan dalam penelitian ini, maka pendekatan penelitian yang digunakan adalah pendekatan kualitatif fenomenologis, yakni bagian dari metode kualitatif yang mengandung nilai sejarah dalam perkembangannya. Fenomenologi digunakan untuk mengetahui deskripsi peranan partisipasi perempuan dalam lembaga legislatif secara universal, di antaranya menjelaskan latar belakang partisipasi perempuan dalam lembaga legislatif, maksud partisipasi perempuan dalam lembaga legislatif dan sebab akibat partisipasi perempuan dalam lembaga legislatif tersebut. Peneliti menggunakan sudut pandang kelas, ras dan budaya etnis Jawa. Oleh karenanya dalam situasi yang multikultural tersebut mendasarkan penelitian pada seperangkat ide-ide, kerangka teori (ontologi) yang menentukan seperangkat pertanyaan, metode (epistemologi) yang kemudian diselidiki (metodologi/ analisis) dengan cara yang spesifik.

Permasalahan umum yang sering terjadi adalah partisipasi perempuan dalam berbagai bidang politik yang masih kurang. $\mathrm{Hal}$ ini terjadi di semua kabupaten di Indonesia, meskipun dengan berbagai faktor penyebab dan latar belakang yang berbeda. Keadaan yang timpang pada perempuan tentu saja akan mempengaruhi seluruh aspek kehidupan masyarakatnya, karena hampir $50,63 \%$ masyarakat kabupaten Kendal adalah perempuan. Untuk itu peneliti mengambil lokasi penelitian di lembaga legislatif kabuapaten Kendal sebagai kasus yang juga relevan untuk diteliti.

Sasaran penelitian ini adalah perempuan yang duduk dalam lembaga legislatif di Kabupaten Kendal. Datadata dalam penelitian diperoleh dengan menggunakan teknik wawancara mendalam (indepth interview), observasi dan dokumentasi. Wawancara mendalam dilakukan terhadap sejumlah informan, agar peneliti memperoleh deskripsi yang utuh tentang partisipasi perempuan dalam lembaga legislatif dan peran perempuan dalam penentuan kebijakan di lembaga legislatif kabupaten Kendal. Peneliti 
melakukan observasi terhadap anggota dewan perempuan pada saat rapat paripurna, rapat fraksi, rapat komisi, cara me-lobby anggota dewan laki-laki dan lainnya.

\section{HASIL DAN PEMBAHASAN}

Partisipasi Perempuan dalam Lembaga Legislatif di Kabupaten Kendal, dari enam partai politik yang terdapat dalam lembaga legislatif di kabupaten Kendal yakni PDIP, PKB, PPP, PAN, GOLKAR dan Demokrat, hanya PDIP dan GOLKAR saja yang mempunyai wakil Anggota dewan perempuan di Kabupaten Kendal terdiri dari empat orang yakni dr. Hj. Widya Kandi Susanti dan Hj. Nuryati dari Fraksi Partai Demokrasi Indonesia Perjuangan, $\mathrm{Hj}$. Supartinah dan Dra. Hj. Siti Nurmarkesi dari Fraksi Golkar. Meskipun secara kuantitas hanya empat orang saja, namun mereka berusaha optimal dalam hal kualitas, hal ini terbukti dengan terpilihnya Dra. Hj. Siti Nurmaikesi sebagai wakil bupati Kendal.

Agenda politik perempuan di lembaga legislatif kabupaten Kendal adalah: Penghapusan kekerasan terhadap perempuan dan sosialisasi kesehatan reproduksi perempuan. Beberapa persoalan pokok kesehatan reproduksi yang dihadapi perempuan di kabupaten Kendal adalah : masih rendahnya angka penyebaran pelayanan kesehatan seperti Puskesmas, ada semacam ketakutan menghadapi berbagai resiko jika berbicara mengenai pendidikan seks dan penanganan abortus, hukum yang tidak memihak kepada kesehatan reproduksi perempuan, masih banyaknya adat yang memiliki resiko tinggi bagi kesehatan reproduksi yang dilandasi kebiasaan dan kepercayaan, masih kuatnya budaya patriarki sehingga untuk hamil," memiliki anak dan pemilihan alat kontrasepsi ditentukan oleh laki-laki (suami), penafsiran moral yang sering tidak konsisten khususnya mengenai nilai keperawanan, janda, pelacuran dan abortus (Wardani, 1999). Perlindungan buruh migran perempuan. Hal ini menjadi sangat penting karena Kendal merupakan salah satu daerah pemasok TKW terbesar di Jawa Tengah. Penghapusan perdagangan perempuan dan anak. Anggota dewan perempuan berusaha memperjuangkan solusi dari berbagai permasalahan yang dialami perempuan di kabupaten Kendal di atas melalui kebijakan- kebijakan publik yang berperspektif gender, misalnya dalam bentuk PERDA yang sensitif gender.

Minimnya keterwakilan perempuan dalam lembaga legislatif di kabupaten Kendal juga tidak lepas dari kendala-kendala yang menghambat gerak langkahnya, diantaranya adalah: kendala sistem politik yakni: kelaziman model maskulin mengenai kehidupan politik dan badan-badan pemerintahan (laki-laki mendominasi politik, memformulasi aturan permainan politik, dan menentukan standar untuk evaluasi, bahkan kehidupan politik diatur oleh norma-norma dan nilai-nilai laki-laki). Kendala sosial budaya. Masyarakat Kabupaten Kendal masih terikat kuat oleh budaya Jawa yang cenderung patriarki. Kendala psikologis : perempuan takut berkuasa, karena beberapa parpol Islam menunjukkan keberatannya atas partisipasi perempuan pada aspek politik. Kendala sosial ekonomis, yakni adanya pemiskinan perempuan.

Dengan berbagai kendala yang muncul tersebut di atas menghambat perempuan untuk maju dalam aspek politik apalagi untuk berpartisipasi dalam lembaga legislatif. Sesuai dengan konsep kemitrasejajaran dalam teori kesetaraan peran laki-laki dan perempuan menjadi poin penting dalam perwujudan demokratisasi sebuah negara. Dalam terminologi politik yang bias gender, untuk waktu yang lama pengertian partisipasi "dari rakyat, oleh rakyat dan untuk rakyat " ini hanya diartikan secara terbatas untuk beberapa kalangan tertentu dalam masyarakat dan ini sudah tentu tidak termasuk perempuan di dalamnya. Walaupun saat ini hak-hak politik bagi perempuan sudah banyak diakui, namun adanya hak-haknya politik tersebut tidak menjamin adanya pemerintahan sistem politik yang demokratis di mana masa partisipasi, representasi dan akuntabilitas di beri makna yang sesungguhnya. Ini artinya, adanya keterwakilan perempuan didalamnya dan berbagai kebijakan yang 
muncul memiliki sensivitas gender tidak serta merta terwujud meskipun hak-hak politik perempuan sudah diakui. Perempuan sebagai warga negara seharusnya dapat berpartisipasi secara mandiri dalam proses demokrasi ini.

Mempertimbangkan kepentingan perempuan dan melibatkan laki-laki dan perempuan dalam proses pembuatan kebijakan adalah dasar dari kerangka demokrasi yang mendorong ke arah kesetaraan dan keadilan gender. Jika membicarakan partisipasi politik perempuan secara global maka kita harus melihatnya dalam konteks sosial budaya, ekonomi serta kondisi geografis yang sangat bervariasi. Perempuan di Kabupaten Kendal juga lidak homogen, karena mereka berasal dari berbagai kelas sosial, wilayah, etnis maupun agama yang berbeda. Perempuan dalam kategori tersebut memiliki masalah spesifik yang harus diselesaikan. Beberapa kondisi yang perlu diperhatikan untuk memahami tantangan yag harus dihadapi perempuan sebagai berikut: budaya Indonesia feodal dan patriarki, pemahaman dan interpretasi konservatif masyarakat Indonesia terhadap ajaran agamanya yang juga beragam dan hegemoni negara yang direfleksikan dalam instisusi-institusi negara yang terus-menerus mempertahankan budaya patriarki.

Budaya patriarki yang mengakar dan sistem politik yang didominasi oleh lakilaki memiliki dampak negatif yang besar bagi upaya perempuan untuk berpartisipasi dalam Lembaga Legislatif. Perempuan tidak didukung dan bahkan dalam banyak hal malah dihambat, untuk mengambil peran aktif di ruang publik. Sebaliknya, mereka diharapkan untuk menggunakan kemampuannya di lingkungan rumah tangga, yang dianggap sebagai ruang privat. Bahkan pada masa reformasi sekarang ini, dikotomi konsep ruang publik privat masih mendominasi masyarakat Indonesia yang mengakibatkan perempuan Indonesia harus mengatasi praktek diskriminasi dan buta gender (gender blind) dalam badan legislatif (Soetjipto, 2005:236-237).

Nilai budaya tradisional yang sudah terinternalisasi ini mengakibatkan sebagian besar perempuan secara psikologis menjadi tidak siap untuk berpartisipasi aktif di bidang politik. Sebagian memiliki perasaan rendah diri dan yakin bahwa mereka tidak memiliki keahlian dan kemampuan yang dibutuhkan untuk berkecimpung dalam dunia politik. Sebagian lainnya enggan memasuki dunia politik karena konotasi negatif dari dunia politik itu sendiri.

Hambatan juga muncul dengan adanya peran ganda perempuan, bahkan dalam banyak kasus multi ganda yakni sebagai ibu rumah tangga, pekerja dan masyarakat profesional. Tidak terdapat waktu yang memadai dengan banyak peran tersebut untuk memasuki dunia politik. Tidak ada upaya strategis yang dilakukan oleh organisasi poltik untuk mengatasi hambatan- hambatan tersebut dan juga tidak ada upaya untuk memahami dan mengakomodasi peran ganda perempuan tersebut. Sebagai contoh, pertemuan maupun kegiatan-kegiatan politik, terlepas itu memang disengaja maupun tidak, secara intens dilaksanakan pada malam hari dan bahkan seringkah dilakukan di luar kota. Sehingga semakin sulit bagi perempuan untuk dapat menghadirinya.

Secara keseluruhan, peran perempuan yang sangat terbatas dalam pembuatan kebijakan dan posisi kepemimpinan disebabkan oleh kondisi sosial budaya yang mempersulit perempuan untuk terlibat secara penuh didalamnya. Tingkat pendidikan perempuan yang pada umumnya rendah serta faktor kemiskinan yang mereka alami semakin memperburuk permasalahan ini. Hal ini terlihat dengan banyaknya perempuan yang tidak peduli terhadap hak politiknya. Dalam situasi di mana mayoritas laki-laki tidak menyadari pentingnya partisipasi perempuan yang setara serta rendahnya dukungan sosial dan keluarga membuat perempuan semakin sulit untuk mengatakan tidak mungkin terlibat dalam dunia politik.

Berdasarkan teori pengambilan keputusan dalam lembaga legislatif yang dikemukakan Bem dalam Megawangi bahwa sulitnya mengubah figur dominan wanita sebagai ibu, disebabkan belum adanya 
kemauan politik secara dalam menciptakan kultur yang kondusif bagi terciptanya kesetaraan gender. Begitu juga perempuan di KabupatenKendalsulitmenggapaikekuasaan sebab masih dalam kategori perempuan tradisional yang mempunyai stereotip tidak mengenal kekuasaan. Kefeminiman juga tidak memuat ketegaran, keperkasaan atau ketegasan yang merupakan inti kekuasaan. Gambaran klasik mengenai kefeminiman identik dengan kepasrahan, kepatuhan, kesetiaan, kemanjaan, kekanak- kanakan, kesimpatikan, kehangatan, kelembutan, dan keramahan. Sedangkan kekuasaan identik dengan maskulinitas di mana ketegaran dan kekuatan serta mempengaruhi orang lain menjadi bagian yang sangat penting. Dengan demikian tidak mengherankan bahwa secara tradisional dalam diri perempuan tidak memikirkan kekuasaan sebagaimana lakilaki mendefinisikan hal tersebut dalam diri mereka (Soetjipto, 2000; Utami, 2010; Wardani, 2009).

Dalam mengupayakan kesetaraan pemerintah melakukan tindakan khusus sementara (affirmative action). Menurut Ani Widya Soetjipto (2005) affirmative action adalah tindakan strategis yang harus diambil sebagai temporary special measures untuk percepatan peningkatan representasi perempuan dalam politik. Affirmative action mempunyai dua sasaran yakni dampak positif terhadap suatu institusi agar lebih cakap dalam memahami dan sekaligus mengeliminasi berbagai bentuk rasisme dan seksisme di tempat keija dan agar institusi itu mampu mencegah terjadinya bias gender maupun bias ras dalam segala kegiatannya. Ketika sasaran untuk mencapai kesetaraan telah dicapai dan jika kelompokkelompok yang dilindungi telah terintegrasi, maka kebij akan ini akan segera dicabut.

Tindakan affirmative action ini secara berangsur-angsur akan menjamin bahwa perempuan yang berada dalam institusi pengambilan keputusan mempunyai kualifikasi untuk memegang berbagai jabatan. Tindakan affirmative action yang dilakukan pemerintah adalah dengan adanya kuota $30 \%$ keterwakilam perempuan dalam lembaga-lembaga politik. Dalam upaya mempersempit gender gap (jurang perbedaan antara laki-laki dan perempuan) dalam representasi dalam lembaga legislatif kebijakan kuota adalah kebijakan yang bermanfaat karena dalam waktu singkat dapat membuka jalan masuk bagi lebih banyak perempuan untuk berkiprah didalamnya. Semua kebijakan tersebut adalah langkah strategi menuju penciptaan critical mass (jumlah yang signifikan) sehingga perempuan dapat berpartisipasi dalam proses pengambilan keputusan di lembaga legislatif.

Sebesar apapun upaya pemerintah tidak akan maksimal ketika perempuan sendiri tidak melakukan pembenahan diri. Berikut merupakan upaya yang bisa dilakukanoleh kaum perempuan untuk dapat berpartisipasi aktif dalam perpoltikan terutama dalam lembaga legislatif: mengiatkan kegiatan kegiatan penyadaran (awareness raising), misalnya sosialisasi gender terutama yang dapat mengubah cara pandang dan pola pikir tentang prinsip-prinsip demokrasi yang menjamin kesetaraan, HAM, supremasi hukum dan keadilan. Mengubah kebijakan publik dengan mengupayakan berbagai advokasi dan strategi (mengamandemen peraturan partai tau UU Pemerintah yang memperbolehkan diskriminasi terhadap perempuan), pengorganisasian massa dengan mengangkat isu-isu krusial (mendekatkan diri pada media untuk meningkatkan kepedulian pada masalah-masalah perempuan), membentuk alinasi atau koalisi (membangun dan mempertahankan jaringan dengan organisasi perempuan baik dalam politik maupun organisasi masyarakat sipil lainnya) dan bekerja dalam kemitraan dengan anggota dewan laki-laki (Kweldju, 1993; Sadli 2010).

Guna mewujudkan suatu tatanan masyarakat yang demokratis, maka harus melibatkan semua pihak, sehingga tidak ada bagian dari masyarakat yang merasa terpinggirkan. Begitu pula dalam setiap penentuan kebijakan diperlukan peran serta seluruh anggota dewan baik laiki-laki maupun perempuan. Peran perempuan dalam lembaga legislatif di kabupaten Kendal tampaknya belum bisa maksimal, hal ini bisa dilihat dari posisi mereka dalam 
setiap kegiatan. Anggota dewan belum ada yang diberi kesempatan untuk menempati posisi ketua sebagai posisi utama penentu kebijakan. Posisi ketua maupun wakil ketua dalam pimpinan dan alat kelengkapan DPRD Kabupaten Kendal semuanya ditempati oleh anggota dewan laki-laki. Seharusnya bisa saja, demi terciptanya ekosistem yang seimbang dalam tubuh DPRD kabupaten Kendal salah satu diantara ketiga posisi di atas diberikan kepada perempuan. Karena bagaimanapun juga tanpa adanya kesempatan bagi perempuan tidak mungkin bisa maju, apalagi anggota dewan laki-laki dan perempuan memiliki hak yang sama untuk menempati posisi sebagai ketua maupun wakil ketua. Dengan masuknya perempuan sebagai ketua atau wakil ketua diharapkan dapat selalu memasukkan agenda politik perempuan dalam setiap kebijakan sehingga dapat menghasilkan kebijakan publik yang berperspektif gender.

Anggota dewan perempuan tidak bisa berpartisipasi dalam seluruh jenis rapat yang diadakan oleh DPRD kabupaten Kendal misalkan dalam rapat pimpinan dan rapat gabungan pimpinan $\mathrm{DPRD}$, mengingat posisi mereka hanya sebagai anggota dalam setiap struktur organisasi. Hal ini sangat merugikan bagi kaum perempuan dan anggota dewan perempuan khususnya, sebab rapat tersebut biasanya membahas hal-hal penting seputar kebijakan publik. Tidak ikutnya anggota dewan perempuan mengakibatkan kebijakan yang dihasilkan belum terlalu memasukkan kepentingan perempuan, sebal hanya dipandang dari kacamata lakilaki saja. Apalagi sebagian besar keputusan kebijakan publik diputuskan melalui voting (pengambilan suara terbanyak). Dengan sistem pemungutan suara yang merifhitung langsung setiap anggota DPRD yang hadir akan menguntungkan laki-laki, perempuan akan kalah dengan sendirinya, sebab secara kuantitas tidak proporsional. Untuk itu anggota dewan perempuan harus mengatur strategi dengan melakukan "lobby" dengan anggota dewan laki-laki. Diharapkan kerjasama ini dapat membuka akses anggota dewan perempuan untuk menyalurkan aspirasinya dalam memperjuangkan kepentingan perempuan.

Posisi duduk dalam rapat juga mempengaruhi suara yang didapatkan. Untuk rapat tertentu anggota dewan perempuan duduk sesuai dengan daftar nama yang sudah diletakkan di atas meja rapat, memang memungkinkan untuk berkomunikasi antar anggota dewan perempuan, tetapi dengan posisi duduk tersebut mereka tidak bisa membaur dengan anggota dewan laki-laki untuk melakukan lobby, seperti pada rapat paripurna.

Meskipun demikian hal tersebut tidak menghambat kinerja anggota dewan perempuan di Kabupaten Kendal dalam memperjuangkan kepentingan perempuan melalui berbagai kebijakan yang berperspektif gender. Diantaranya dengan mengupayakan mekanisme counter terhadap kebijakan publik, yakni melalui legal drafting (kebijakan keuangan yang resmi). Kebijakan publik harus memperhatikan anggaran berperspektif gender dalam APBN maupun APBD. Hal ini bertujuan untuk mendukung terciptanya kesetaraan gender, mengarahkan dan menjadi acuan secara menyeluruh dalam pelaksanaan kebijakan dan program pemerintah yang berdampak pada kemajuan taraf hidup seluruh masyarakatterutama masyarakat miskin, anak-anak dan perempuan serta pertanggungjawaban pemerintah dalam melaksanakan pembangunan di wilayahnya. Ada tiga hal penting sebagai tolok ukur untuk menilai apakah alokasi anggaran tersebut berperspektif gender, yakni berapa anggaran untuk kebutuhan khusus bagi perempuan dan anak, berapa anggaran untuk mempercepat tercapainya kesetaraan lakilaki dan perempuan,dan berapa anggaran untuk pengarusutamaan gender dalam seluruh kebijakan dan program pemerintah. Guna menjalankan upaya di atas diperlukan aksi- aksi advokasi yang efektif dan efisien, diantaranya: non litigasi (lobi) (dengar pendapat (hearing), kampanye), litigasi (legal standing, class action, counter legal, synectic, brainstorming).

Sedangkan untuk mencalonkan diri menjadi anggota DPRD, politikus perempuan harus mengupayakan hal-hal seperti berikut 
ini, menyusun pedoman kerja, membentuk tim kampanye sendiri, penggalangan dana, demonstrasi, boikot, revolusi.

\section{SIMPULAN}

Berdasarkan hasil penelitian dan uraian di atas dapat ditarik simpulan sebagai berikut: permasalahan perempuan di Kabupaten Kendal sangat kompleks, di antaranya disebabkan oleh kuatnya budaya patriarki di masyarakat yang mempengaruhi seluruh sendi kehidupan dan banyaknya kebijakan publik yang belum berperspektif gender akibat rendahnya partisipasi perempuan dalam politik terutama dalam lembaga legislatif sebagai penentu kebijakan. Rendahnya partisipasi perempuan dalam lembaga legislatif di Kabupaten Kendal dikarenakan banyaknya kendala yang dihadapi perempuan untuk maju ke ranah politik, seperti kendala sosial budaya, politik, psikologi dan ekonomi. Sebagian besar masyarakat Kabupaten Kendal merupakan masyarakat yang religius yang memiliki pandangan timpang mengenai eksistensi perempuan dan menjustifikasi dengan ayat- ayat suci Al-Quran sehingga perempuan terdiskriminasi dalam banyak hal tak terkecuali dalam kehidupan politik. Untuk itu hendaknya semua pihak harus berperan aktif dalam memberdayakan perempuan dalam politik guna peningkatan kualitas hidup secara global.

\section{DAFTAR PUSTAKA}

Kweldju, S. 1993. Kodrat dan Posisi Wanita dalam Perubahan: yang terungkap oleh Seksisme dalam Bahasa Indonesia. Jurnal Penelitian IKIP Malang. Vol III. No. 3 Juni. Hal 51.

Sadli, S. 2010. Pemberdayaan Perempuan dalam Perspektif Hak Asasi Manusia dalam Penghapusan Diskriminasi terhadap Perempuan. Jurnal Perempuan. No 45: Hal: 78.

Salim, A. 2001. Teori dan Paradigma Penelitian Sosial. Yogyakarta: PT Tiara Wacana Yogya.

Soetjipto, A. 2005. Politik Perempuan Bukan Gerhana. Jakarta: Kompas.

Soetjipto, A. 2000. Perempuan dan Politik Indonesia. Jurnal Pemikiran Islam tentang Pemberdayaan Perempuan. Vol 5. Hal 120.

Utami, TS. 2010. Perempuan Politik di Parlemen, Sebuah Sketsa Perjuangan dan Pemberdayaan 1999-2001. Jurnal Perempuan 48. Hal: 128.

Wardani, S\&dkk. 2009. Aspirasi Perempuan Anggota Parlemen terhadap Pemberdayaan Politik Perempuan. Jurnal Perempuan 47. Hal 89.

Wijaksana, MB. 2004. Modul Perempuan untuk Politik. Jurnal Prisma. No. $7 \mathrm{Hal}$ : 3 . 